ISSN 2519-2523 (print)

DOI: $10.18524 / 2519-2523.2020 .15 .218675$

УДК 94(477.7) “1804-1886”

\title{
CONVERSION TO ISLAM AMONG EMIGRANTS FROM UKRAINE IN THE MIDDLE OF THE XIX CENTURY: THE CASE OF MYCHAYLO CZAJKOWSKI (MEHMED SADYK-PASHA)
}

\section{Volodymyr Poltorak}

ORCID: https://orcid.org/0000 000304066907

PhD (History), Associate Professor

Odessa I.I. Mechnikov National University

2, Dvoryanska Str., Odessa, 65082, Ukraine

poltorak@onu.edu.ua

In the middle of the 19th century, the multi-ethnic and multi-religious Ottoman Empire gave refuge to representatives of the national liberation and revolutionary movements in Central and Eastern Europe. The popularity of Orientalism in Western culture has opened up to Europe the riches of Islamic cultural heritage. One of the participants in this process was a popular novelist, politician, military man from Volyn Mychaylo Czajkowski.

In 1850, along with many refugees and emigrants, Mychaylo Czajkowski converted to Islam and lived in the Ottoman Empire for almost three decades. His writings and correspondence allow us to trace how he perceived the Islamic Empire from within, how he perceived the Islamic religion from the point of view of a newly converted Muslim. His case is characteristic and unique at the same time, it allows a different look at Ukrainian-Islamic contacts in modern times.

The work of Sadyk Pasha, who opened the veil of the Islamic world to the Ukrainian, Polish, French, and Russian readers, should be singled out. The images of the Muslim, the Turk, the Ottoman were humanized by him, the barriers of misunderstandings and accusations were shaken. The past of the relationship is filled with examples of cooperation. The future looks full of joint projects and accomplishments. Sadyk Pasha's personal destiny testifies to understanding, to the tolerance of evaluation - to the expansion of the values of modern times.

Key words: Mehmed Sadyk-pasha (Myhaylo Czajkowski), Ottoman Cossacks, conversion to islam.

Володимир Полторак

ORCID: https://orcid.org/0000 000304066907

Кандидат історичних наук, доцент

Одеський національний університет імені I. I. Мечникова

Вул. Дворянська, 2, Одеса, 65082, Україна

poltorak@onu.edu.ua

\section{НАВЕРНЕННЯ НА ІСЛАМ СЕРЕД ЕМІГРАНТІВ 3 УКРАЇНИ У СЕРЕДИНІ ХІХ СТ.: ВИПАДОК МИХАЙЛА ЧАЙКОВСЬКОГО (МЕХМЕДА САДИК-ПАШІ)}

Мультиетнічна та різноконфесійна Османська імперія у середині XIX cm. дала прихисток представникам національно-визвольних та револючійних рухів ЦентральноСхідної Свропи. Популярність орієнталізму в західній культурі дозволила відкрити для Свропи багатства ісламської культурної спадщини. Одним із учасників цьього процесу став популярний романіст, політик, військовий Михайло Чайковський (Садик-паша). 
У 1850 р. разом з багатьма біжениями та емігрантами Михайло Чайковський прийняв іслам та майже три десятиліття жив в Османській імперії. Його твори та листування дозволяють прослідкувати, як він сприйняв імперію зсередини, як сприймав релігію з точки зору новонаверненого мусульманина. Його випадок характерний $і$ унікальний водночас, дозволяе по- іншому подивитися на українсько-ісламські контакти в модерну добу.

Окремо слід виділити творчість Садик-паші, яка відкрила украӥнському, польському, франиузькому, російському читачеві завісу ісламського світу. Образи мусульманина, турка, османа олюднюються, бар'єри непорозумінь та звинувачень розхитуються. Минуле відносин наповнюється прикладами співпраці. Майбутнє виглядає сповненим спільними проектами та звершеннями. Особиста доля Садик-паші свідчить про порозуміння, про толерування “інакшості" - про поширення цінностей модерного часу.

Ключові слова: Мехмед Садик-паша (Михайло Чайковський), навернення в іслам, османські козаки.

Мультиетнічна та різноконфесійна Османська імперія у середині XIX ст. дала прихисток представникам національно-визвольних та революційних рухів ЦентральноСхідної Свропи. Популярність орієнталізму в західній культурі дозволила відкрити для Свропи багатства ісламської культурної спадщини. Одним із учасників цього процесу став популярний романіст, політик, військовий Михайло Чайковський [6].

«Саме тоді, коли кирило-мефодіївиі задумались над тим, щзо Україна - камінь наріжний слов'янського світу, коли на вулииях Левового міста замайорів жовтосиній стяг руського люду, в Махнівці на межі Волині, Поділля та Київщини молодий хлопчина із захопленням читав «Козацькі повісті» та «Вернигору» волинського емігранта Чайковського. Молодому хлопчині на все життя запам'ятались романтичні характери та епічні постаті, які захопили його народною історією. Вихований в польскому шляхетському середовищі, він «одкрив сам собою украӥнство». Пізніше він створить наукову иколу, стане професором Київського університету, вчителем Михайла Грушевського. А починалось для Володимира Антоновича все зі сторінок «Могили» та інших повістей Михайла Чайковського. При цььому факт, щзо його улюблений автор є мусульманином жодним чином не зупиняв майбутнього лідера громадівського руху в захопленні творами свого кумира [5, с. 175].

Почавши дослідження козацтва як історик та письменник, Чайковський очінив $i$ політичні вигоди козакофільства. Створений ним у 1853 р. козаџький підрозділ у складі османської армї став єдиною можливістю для балканських християн отримати військову освіту та бойовий досвід. Ідеї демократії та національної держави виховувались вже самим духом, щуо панував у козацько-османських полках. Плануючи звільнити слов'янські народи від тиранії, вступити на чолі козацької армї до Києва, Чайковський водночас дбав про поширення освіти, про налагодження культурних мостів між поляками та болгарами, старообрядиями та украӥниями, турками та євреями.

Коло Гальчиния височіла Могила,

В ї̈ підніжжі роздоріжжя перетиналося, наче рамена хреста;

Зверху вона заросла кущами й зіллям,

А всередині, можливо, ховала пам'ятки минулого...»

Так почав видану в Парижі у 1837 р. одну зі своїх перших «повістей козацьких» Михайло Чайковський - 33-літній українськи шляхтич-емігрант. Все життя він марив минулим, яке можлливо ховається в могилі при роздоріжжжі, усе заросле кущами і зіллям. I все життя марення про козацькі часи, про «дружбу народів», бенкети і співи, полювання i верхові герці, шалене кохання i рівність межи людьми штовхали «Михалка з Гальчинця» до нових пригод, нових подорожей і нових життів. 
Від батька отримав він прізвище Чайковський, від діда по матері ім'я архангела Михайла, султан турецький пойменував його при наверненні до ісламу Мехмедом Вірним (Садиком), а сам себе звав він Чайкою - птахом морським і бездомним. Волів бути для світу пророком Вернигорою, а став для нього потурнаком Садик-пашею, підписував себе Гетьманом, а отримав від жорстокого біографа зневажливих епітетів «pół poeta, pół rycerz, pół uczony, półgłówek, pól dyplomata, pół narwaniec i do tego pół Polak» [7, c. 86].

Життя мав довге - 82 роки - комусь стало б на три життя. А йому вистачило на чотири. Чотири життя в чотирикутнику європейських столиць. Трагізму його долі додали біографи - сам він життя любив, ним насолоджувався, і смерті самогубця собі не шукав. Його діти довго не могли повірити у добровільність відходу батька на той світ... .

Станіслав Чайковський гербу Jastrzębiec - батько новонародженого Михайла невдовзі відійшов на той світ. Юнака виховувала мати та іiі рідня - шляхтичі Глембоцькі. Михайлова мати Петронела (в дівоцтві Глембоцька) доводилась правнучкою козацькому гетьманові Іванові Брюховецькому. Цим генеалогічним зв'язком з Гетьманщиною Михайло буде пишатись усе життя.

В старості він із захопленням змалював своє дитинство та парубоцтво на батьківщині. Було там усе - шляхетські розваги, бердичівські ярмарки, лови з хортами, навчання в ліцеї англійця Вольсея та школі братів-піарів в Межиріччі Корецькому. Михайло вперше закохався - в Северину Залевську з Пилип, що в 20 кілометрах на захід. Недосвідчений романтик при рідних тітках коханої визнав, що любить ії̈ наче свого коня, викликавши таким порівнянням неабияке обурення присутніх.

Акценти у спогадах про юність знакові - розповіді про фельдмаршала Івана Гудовича, знайомство з Тимком Падурою, Вацлавом Жевуським, Боніфатієм Антоновичем, Петром Гулаком-Артемовським. «Першим моїм учителем був пан А(нтонович), пристрасний українець-козак, і більшу частину своїх уроків я брав верхи на коні. Крім цього вчителя в мене був старий дядько на ім'я Левко, який оповідав мені казки про знахарів та чаклунів, передавав козацькі історії, показував урочища, в яких відгомоніли криваві баталії, та співав козацькі думи». Свій перший навчальний заклад - Бердичівську гімназію англійця Вольсея - Чайковський красномовно зве «слов'янською мозаїкою», де «дух козацький панував, бо вчителі були гарячими українцями». В цьому «бердичівському гуртку готувались запорозька старовина, думи про українських гетьманів, пісні козацькі та малоруські, які згодом вийшли в Харкові, куди перейшли в університет професорами» усі згадані вчителі.

Молодий шляхтич не стояв осторонь польської політичної боротьби - він був близький до студентських таємних товариств у Варшаві, і коли вибухнуло листопадове повстання, активно до нього долучився. Карл Ружицький (одружений на сестрі Чайковського) сформував волинський повстанський полк і у складі цього підрозділу Михайло бився «За нашу і вашу Свободу», а після поразки перетнув кордони Російської імперії. Саме з ганку свого палацу межи чотирьох колон оголосив він своїм селянам про волю - і закликав їх долучатись до боротьби 3 російською тиранією. Саме звідси, 3 Гальчинецького палацу почалось вигнання, почалась еміграція.

Молодий Чайковський не одразу потрапив до аристократичного готелю «Ламбер» - 1830-ті роки минули в пошуках однодумців та засобів для життя. Юнакові довелось пропонувати свій хист кавалериста та військового аналітика - його статті звернули на себе увагу міністра і колишнього наполеонівського маршала Сульта. Михайло почав писати репортажі з судових засідань, став кореспондентом 
декількох французьких газет. На той час він належав до демократичних кіл польської еміграції, проте згодом почав «дрейф вправо».

Палка пристрасть увінчалась першим одруженням - із Леонідою Габаре, молодою й чарівною дочкою архітектора міста Бурже. Французька дружина відіграла в його житті велику роль - правила чернетки статей та книжок, а згодом народила Михайлові чотирьох дітей [1, с. 254].

Рішучий вплив на молодого журналіста справив Адам Міцкевич - писати польською мовою була його порада. Перша книжка - і шалений успіх «Козацьких повістей» (1837). Потім були повісті та романи «Вернигора» (1838), «Кірджалі» (1839), «Гетьман України» (1841) etc. Ставши популярним письменником, Чайковський продовжив марити українською козаччиною. В Україні уважно читали твори земляка - Тарас Шевченко під час підготовки «Гайдамаків» вивчав «Вернигору», Володимир Антонович із захопленням гортав сторінки козацьких повістей і згодом віддав належне їхньому впливові, визнавши одним 3 чинників відходу від польськості до українськості...

31835 р. Чайковський став співробітничати 3 Французьким Історичним інститутом, який організував у Парижі «Європейський Історичний Конгрес». Виступаючи як спеціаліст з історії козацтва, він виголосив на Конгресі доповідь про вплив козацтва на розвиток літератури. Знаковою виглядає ідентифікація Михайла на Конгресі - серед французів, поляків, турок, росіян та інших народів останнім в переліку згадується «один Козак». У 1841 р. цей «Козак» Чайковський їде 3 документами Історичного інституту до Османської імперії для розшуків козацької старовини. Історична експедиція відкрила перед Михайлом на Сході безкраї можливості. Стамбул саме переживав реформи Танзімату [8, с. 12].

В готелі «Ламбер» Михайло Чайковський запропонував Адаму Чарторийському свої послуги - і очолив Східну Агенцію польського уряду в еміграції. Цей період діяльності яскраво висвітлений в польській та болгарській історіографії - завдяки збереженому листуванню 3 Адамом Чарторийським. У 1840 -х роках Чайковський патронує утворення окремої церковної ієрархії у старообрядців - втікачів з Росії, домагається відділення від вселенського патріархату болгарської церкви, веде жваве листування з агентами в Бухаресті, Тульчі та Белграді. Російська дипломатія почала бити на сполох - Микола I особисто вимагав усунення Чайковського зі Стамбула. Шеф жандармів Олексій Орлов в доповідній записці про розкриття КирилоМефодіївського товариства зазначив, що керує усіма антиросійським діями «Чайковський, який перебуває в Константинополі»... [4, с. 295]. Одразу ж за справою Кирило-Мефодіївського товариства та придушенням Угорського повстання, розпочала російська дипломатія кампанію проти Михайла Чайковського.

В лютому 1849 р. російське посольство у Стамбулі відновило запити щодо видалення Чайковського з берегів Босфора та його агента Ленуара з Белграду. Цього разу сподівань, що зусилля російської дипломатії будуть марними, не було. Ленуар одразу поступився. Хворий, не дужий після кавказької експедиції, виїхав до Парижа. Чайка вчинив інакше. Не міг і не хотів залишати Стамбула. Бачив, що Туреччина не зможе сама його оборонити. Тільки спільні зусилля 3 французькою дипломатією змогли б врятувати його становище. Він намагався затягнути справу, сподіваючись на появу нових можливостей.

Нові можливості не з'являлись, а російське посольство вже категорично вимагало екстрадиції Чайковського. Михайло пішов «ва банк». Він заявив, що якщо Туреччина його не захистить, а Франція відмовить в допомозі - віддасть себе в руки 
Росії. «Я переконаний, що моя позиція відмови від добровольної екстрадиції, натомість здача Москві на певне покарання, а не на ласку, має дошкульно вдарити по Порті та Франції».

Князь Адам Чарторийський суворо прокоментував таку позицію. Але Чайковський не поступався: «Я вимагав, що якщо збираються мене видворити, то нехай завезуть до Одеси разом $з$ агенцією». Ту саму тактику поведінки він вже використав у 1836 р., коли був під загрозою екстрадиції з Парижа: «Якщо виселятимете, - заявляв у префектурі, - віддамся царю до солдатів, на шибеницю». Щоправда наївно було би вважати, що такі заяви вплинули на французьку поліцію.

На захист Чайковського встав новий французький посол генерал Опік. Він нагадував своєму керівництву про заслуги з боку Чайковського, які ті здійснював стільки років як в Туреччині, так і у Франції. При цьому запевняв, що немає жодних доказів антиросійських діянь Чайки у самій Російській імперії. А те, що Петербургові не подобається його діяльність, авторитет серед слов'янських народів, не подобаються послуги, надані Туреччині - не повинно схиляти французький уряд до поступок. Про Чайковського посол висловлювався із щирою симпатією. Проте міністр іноземних справ генерал Ла Хітте вирішив справу суто формально Чайковський не натуралізований француз, користується лише протекцією Франції, $\mathrm{i}$ нема підстав не піти назустріч вимогам росіян.

Чайковський вбачав недостатніми зусилля готелю «Ламбер» в напрямі вирішення його справи. Особливо звертав увагу на лицемірну гру графа Владислава Замойського, з яким фактично перебували у стані конфронтації. Припускав, що граф намагається використати ситуацію і замість Чайковського на чолі Агенції Східної поставити бажає свого агента Косцєльського.

4 листопада 1850 р. посол Опік з великою прикрістю повідомив Чайковського, що французький уряд відмовив тому в протекції. Розчарований у французькій позиції, той сам взяв на себе відповідальність щодо власної долі. Розумів, що повернення до Парижа не вирішить проблеми, бо там очікував продовження цькувань. Тому відповів французькому послові: «Повернувшись до Парижа, не матиму жодної певності, що не буду далі висланим і вимушеним поїхати до Америки, якщо б того закортіло уряду петербурзькому». А далі Михайло засвідчив своє бажання знайти інше вирішення проблеми.

Мислив у ті тяжкі часи прийняття рішення: «Держава Османська на моє переконання це єдина організована антимосковська сила, і рано чи пізно між тими державами наступить битва остаточна, до котрої обидві сторони готуються... В Царгороді замайорів польський стяг... Бог так присудив, аби я був тим хто той стяг встановив... Уряд петербурзький відчув ту перешкоду i розсудив, що найпрактичнішим засобом повалення того стягу, було примусити мене до втечі чи відступу» [1, с. 293].

Турки щиро раді були його залишити, але після скасування французької протекції відчували слабкість позицій перед Петербургом. Право остаточного рішення належало султанові, але й він вагався. Саме в цей момент 3 наближених до Абдул-Меджида кіл вийшла пропозиція пристати Чайковському до ісламу.

Пізніше Чайковський в листі до князя Чарторийського відзначив: «Султан відзначив Решид-паші і мені через Етхем-пашу, що не підтримує мого повернення до Парижу, не підтримує мого виїзду 3 Туреччини, але бажає, аби я став мусульманином... і таким чином опинюсь під протекцією султана, стану вузлом, що зв'яже султана 3 князем і Польщею». 
В пізнішій розмові 3 Етхем-пашею Чайковський висловив свої заперечення: «Зазначив, що дві речі утримують від того кроку - недовіра до сили та рішучості турецького уряду та погляд на думку поляків, котра той вчинок сприйняла б, як негідну комедію... Таке рішення є натуральне в цей момент, проте скомпрометує моє добре ім'я для Польщі». Зазначив, що якщо б його за вимогою Росії екстрадирували як і генерала Юзефа Бема в якісь віддалені провінції, не був би тоді корисний ані Туреччині, ані Польщі.

У відповідь запропоновано йому, щоби висловив свої вимоги султанові особисто. Розмови ці точились в таємниці, до якої мали доступ декілька осіб 3 султанського оточення.

Проводячи переговори з Туреччиною, Чайковський не втрачав надії, що якесь «диво» вирве його з такого становища. Чарторийський теж шукав варіанти. Хтось навіть запропонував Чайковському отримати американське громадянство. Були здійснені навіть певні кроки в цьому напрямі. Проте усім цим зусиллям завадило наступне листування.

Владислав Замойський до Михайла Чайковського. Париж, 26 листопада 1850. «Не знаю, чи повинен тобі писати. Не знаю, чи лист цей застане, не знаю - аж мороз душу бере - i питання мене хвилює, ким ти зараз є! Не відаю, якою мовою звідти писатимеш... На все маєш мені відповісти. Всі аргументи, всі почуття найсердечніші і найсуворіші слова не виправдовують дивного незрозумілого рішення твого... I вчинок, який задумав, навіть в задумі $є$ зрадою, а недовіра буде вічним соромом не лише для тебе самого, а для нащадків твоїх, для Польщі, котра лише як зрадника буде тебе вважати... Бажаю, аби публічно усунувся від агенції. По багаторічній праці $є$ певна хвала і в самовольному залишенні агенції. То сьогодні моя порада, не повідомив ще князеві. Але якщо не дослухаєшся, князь дізнається про все».

Відповідь Михайла Чайковського Замойському. Стамбул, 5 грудня 1850 p. «Полковник, мені радиш піти 3 агенції добровільно і передати справи панові Косцєльському... Що ж, по усуненню з агенції і передачі усіх справ, буду вільним розпоряджатися власною особою».

В готелі «Ламбер» з неприємним здивуванням отримано депешу про передачу справ від Чайковського графові Владиславові Косцєльському. У відповідь надіслана від Чарторийського депеша: «Об’явити агенту головному (М.Чайковському) утриматися до останнього і не поступатись... і не складати управління, тільки за крайніх умов». Отже, Адам Чарторийський не розгадав макіавелівських інтриг свого племінника Владислава Замойського, але й не підтримав рішення Чайковського про залишення посади головного агента у Стамбулі. В тій самій депеші 17 грудня від Чарторийського до Чайковського проінформовано останнього про кроки до отримання йому американського громадянства, яке давало б йому можливість залишитись у Стамбулі. «Турки люблять і вміють затягувати справи, і якщо тягнуть їх вже стільки часу, то ще півтора місяці потягнуть, доки сподівана натуралізація (прийняття американського громадянсвта) нас урятує».

Проте було запізно. Доля Чайковського була вирішена, і той повідомив в готель «Ламбер»: «Завтра приймаю іслам і стаю підданим султана Османської держави... Моє життя політичне напевне скінчилось, але я переконаний, що мету, яку поставив, досягнув. Султан і каліф, приймає мене за свого підданого... I водночас, хто б не став на моє місце, стяг пана князя зостанеться піднятим в Царгороді - для Поляків, для Русинів, для Слов'ян...» 
Владислав Косцєльський натомість пише до Владислава Замойського 3 Пери (район Стамбула) 29 грудня 1850 р. «Ото як гром впала на мене звістка про перехід Чайковського до ісламу... Чайка приховував своє рішення, аби його не змогли від нього відмовити. Не можемо подолати нещастя цього, маємо тепер шукати користь для справи. Може бути ця користь велика, а тому заклинаю, пане полковнику, в ім'я душі твоєї, в ім'я стільки разів доведеного патріотизму, не дратуй того чоловіка. Якщо не маєш до нього добрих слів, то принаймні не картай суворо... Був у генерала Опіка. Зустрів не суворого суддю, а змученого приятеля. Так був розчулений, що за декілька хвилин тримав мою руку і слова вимовити не міг... Тітов (працівник російського посольства у Стамбулі. - В. П.) бажав, щоб Чайковського було інтерновано, але султан йому відмовив. Чайковський відмовився від усіх надань, бажав нужду терпіти, але не прийняти від турків нічого. Врешті, в такому нервовому становищі перебуває, що ніхто до нього приступити не може».

Про свій крок Чайковський без затримки надіслав повідомлення Юзефу Бему, який перебував в Алеппо і прийняв іслам у 1848 р. Проте це повідомлення вже не застало того в живих - Бем помер 10 грудня 1850 р. [1, с. 297]. Новий розділ біографії Чайковський розпочав на самоті, вибудовуючи самостійно свою подальшу політичну кар'єру в Османській імперії.

Чайковський ніколи не був фанатичним католиком, питання віри для нього стояло далеко не на першому плані. Пізніше, вже залишивши Османську імперію, він спокійно охрестить свою дочку за православним обрядом і проситиме російського монарха стати ії хрещеним батьком.

У своїх спогадах Михайло Чайковський пригадує випадок, який стався із ним новонаверненим мусульманином у наданому йому чифліку Сазли-Босна під Стамбулом. Побудувавши там невелику мечеть, він послідовно почав виконувати усі настанови ісламу, за що отримав від сусідів-мусульман засудливі погляди. Його навіть почали сприймати фанатиком. Це не дивно, адже неофіт повинен був довести свою рішучість у сповідуванні ісламу [9, с. 673].

Маючи особливий погляд на майбутнє Східної Європи, Мехмед Садик заходився реалізовувати фантастичну ідею всеслов'янського союзу під сюзеренітетом нащадка сербських королів - османського султана. Консервативна католицька польська еміграція відвернулась від колишнього свого представника. Козацтво стало головним засобом i головним гаслом Чайковського. В його уяві Гетьман України на чолі козацької кінноти 3 тріумфом вступав на старокиївські гори - і вказував булавою в бік Москви...

У 1855 p. у Стамбулі помер друг і вчитель Михайла Чайковського як письменника - Адам Міцкевич [3;80]. В нетрях кварталу Бейоглу, неподалік респектабельного Таксіму, провів останні тижні свого життя польський геній. Чорна плита на нижньому поверсі повідомляє, що тут помер і був початково похований Міцкевич. А приїхав до Стамбула він на запрошення Садик-паші. Вони разом мріяли про відродження Польщі в союзі з Україною-Руссю - i разом захоплювались кавалерійською звитягою османських козаків. Міцкевич і Садик-паша запропонували мільйонеру Якобу Ротшильду підтримати козацтво - i утворити в його складі окремий єврейський гусарський полк! Передчасна смерть Міцкевича обірвала ці плани, що як для свого часу виглядали наскільки екстравагантними, настільки ж провісницькими. Мине якихось півстоліття - і буде в Києві гетьман, і будуть по Вкраїні вільні козаки.

Як же при цьому оминути увагою козаків Чайковського. Полк перший був утворений у 1853 р. Він взяв участь у Кримській війні (діяв під Силістрою, Журжею, Бухарестом, Галацем та Тульчею), потім охороняв кордони з Грецією, дислокувався на Косовому полі, 
в Шумені, Едірне, Сливені тощо. Декілька сотень добровольців з козаків взяли участь у франко-прусській війні на боці Франції. Згідно з переліком турецьких підрозділів, козаки обороняли Плевну. За даними Івана Стойчева, підрозділ був знищений російською артилерією в бою під Горним Дубняком у жовтні 1877 р. У 1854 р. утворений другий полк - він став називатись драгунським. Його бойовий шлях тривав дещо довше - до 1886 р., коли драгуни були розформовані. Часто два підрозділи називають «слов'янськими легіонами» - в них служили поляки, болгари, росіяни, українці, серби. Були серед козаків i угорці, євреї, румуни, турки, черкеси. Справжній іноземний легіон в складі турецької армії. До 1871 р. офіційною мовою полків була слов'янська (в спогадах Чайковського вона зветься «малоросійською» - напевно так переклав 3 оригіналу штатний перекладач «Русской старины» більш властиву творам Михайла «українську мову»).

Останні десятиліття Чайковського були завершенням його життєвої «Одіссеї» він повернувся до своєї омріяної козацької України. Карколомний як для його сучасників оберт долі - польський повстанець, турецький генерал скористався амністією російського імператора і повернув до України.

Але що то був за час? Покровителька козацтва в Туреччині, Франція розгромлена Другим німецьким Рейхом. Австрія стала Австро-Угорщиною. Османська імперія загрожена слов'янським повстанським рухом відступила від ліберальної моделі модернізації і впритул наблизилася до перемоги турецького націоналізму. Польський визвольний рух став на шлях еволюційний. Імперія Російська переживала небачені реформи - селяни звільнені, перед судом усі рівні, автономія університетів, обмеження цензури, земства... У вільнодумців першої половини XIX століття голова йшла обертом від можливостей. А у відставного турецького генерала пробудилась туга за батьківщиною. Тож нічого дивного і непередбаченого.

Перші роки жив в Києві. На пенсію від султана, гонорари від друку книжок та подарунки від Олександра II. Спробував стати агентом впливу на польську громаду але був холодно проігнорований. Заходився писати спогади - пережив наново усе своє життя. Активно листувався з ветеранами османського козацтва. Придбав маєток в Чернігівській губернії і перебрався туди.

Знову став батьком - третя дружина грекиня Ірена Теосколо подарувала йому доньку. Старший син Адам вступив до російського війська - і вже після смерті батька дослужився до чину генерал-майора. Останнє повідомлення про нього - звіт Сімферопольського ВЧК про конфіскацію в 1919 р. у генерал-майора у відставці Чайковського фамільної шаблі, яка належала гетьману Брюховецькому. Молодший син Владислав зробив кар'єру при дворі султана - вершиною ії стало управління Ліваном у 1900-1907 pр. Дві доньки лишились спочатку на Балканах, згодом Кароліна перебралась до Трієсту, де й померла у 1901 р. Третя, найменша донька Анна отримувала освіту в Смольному інституті в Санкт-Петербурзі.

Респектабельна генеральська старість в пасторальних сіверських пейзажах наближала Чайковського до логічного завершення його життя.

Польський історик Францішек Равіта-Гавронський, користуючись чиїмось особистими свідченнями, докладно змалював останні години Садик-паші в будинку у Бірках поруч Остра. На Різдво до батьків прибула з Петербургу донька. На ранок мати повинна була везти іiі до залізничної станції на потяг. Михайло вимагав, аби Ірена взяла з собою слугу, та відмовлялась. Молодша на сорок років від чоловіка, вона мала коханця - і підстаркуватий Чайковський неодноразово сварився з нею через це. Шантажуючи дружину самогубством, Михайло пішов до своєї спальні. Усю ніч щось писав, а над ранок 3 п'ятизарядним револьвером рішуче увійшов до спальні 
дружини, де також ночувала й донька, сів на край ліжка й вистрелив собі у груди. До кімнати на звук пострілу увійшов російський офіцер, що ночував в одній із кімнат, i переніс вмираючого Садик-пашу до його кімнати. Поки покликали лікаря, Михайло стік кров’ю. Останні слова, що промовив «Усе набридло» [2, с. 98].

Поховали козака-шляхтича у сусідньому селі біля могили його бойового товариша та ад'ютанта Морозовича. Лишався мусульманином - тож православного відспівування не було - лише священник окропив небіжчика святою водою. Російські солдати, присутні при похованні, віддали відставному генералу останню шану.

Отже, у 1850 р. разом з багатьма біженцями та емігрантами Михайло Чайковський прийняв іслам та майже три десятиліття жив в Османській імперії. Його твори та листування дозволяють прослідкувати, як він сприйняв Ісламську імперію зсередини, як сприймав Ісламську релігію з точки зору новонаверненого мусульманина. Його випадок характерний i унікальний водночас, дозволяє по іншому поглянути на українськоісламські контакти в модерну добу.

Окремо слід виділити творчість Садик-паші, яка відкрила українському, польському, французькому, російському читачеві завісу ісламського світу. Образи мусульманина, турка, османа олюднюються, бар'єри непорозумінь та звинувачень розхитуються. Минуле відносин наповнюється прикладами співпраці. Майбутнє виглядає сповненим спільними проектами та звершеннями. Особиста доля Садикпаші свідчить про порозуміння, про толерування інакшості - про поширення цінностей модерного часу.

\section{Джерела та література:}

1. Chudzikowska Jadwiga Dziwne życie Sadyka Paszy o Michale Czajkowskim/Jadwiga Chudzikowska. - PIW, 1971.

2. Rawita-Gawronski Fr. Michal Czaykowski (Sadyk-pasza). Jego zycie, dzialalnosc wojskowa i literacka. / Fr. Rawita-Gawronski. - Zarys biograficzny. - Petersburg, 1901.

3. Segel Harold B. Mieckiewicz and the Juwish legion in memoirs of the Sadyk Pasha (Michal Czajkowski) / Segel Harold B. // The Polish review. - 1965. - Vol. 10. №3. - pp. 78-81.

4. Кирило-Мефодіївське товариство: в 3 т. - К.: Наук. думка, 1990. - Т. 1. - С. 295-301.

5. Короткий В.А. Міхал Чайковський і Володимир Антонович: "Українська школа" польської романтичної літератури і становлення українофільства./ В. А. Короткий. - Вінниця, 2015. $175 \mathrm{c}$.

6. Полторак В. М. У чотирикутнику європейських столиць: Михайло Чайковський та османські козаки в модернізації Південно-Східної Європи./ В. М. Полторак. - Одеса, 2018. $212 \mathrm{c}$.

7. Рибак М. Михайло Чайковський - Мегмет Садик Паша / М. Рибак // Альманах українського національного союзу. - Нью-Йорк, 1971. - С. 86-97.

8. Стойчев И.К. Казак-алая на Чайковски./ И. К. Стойчев. - София, 1944.

9. Чайковский М. Записки / М. Чайковский // Русская старина. - 1898. - Т.95. - Вип. 9. C. 673 .

\section{Referenses:}

1. Chudzikowska, Jadwiga, 1971. Dziwne życie Sadyka Paszy o Michale Czajkowskim. PIW. [in Polish]

2. Rawita-Gawronski Fr., 1901. Michal Czaykowski (Sadyk-pasza). Jego zycie, dzialalnosc wojskowa i literacka. Zarys biograficzny. Petersburg. [in Polish]

3. Segel Harold B., 1965. Mieckiewicz and the Juwish legion in memoirs of the Sadyk Pasha (Michal Czajkowski). The Polish review, 10(3), p. 78-81. [in Polish]

4. Kyrylo-Mefodiivske tovarystvo: U 3 t., 1990. Vol. 1. K.: Nauk. Dumka. p. 295-301. [in Ukranian] 
5. Korotkyi, V. A., 2015. Mikhal Chaikovskyi i Volodymyr Antonovych: "Ukrainska shkola" polskoi romantychnoi literatury i stanovlennia ukrainofilstva. Vinnytsia. 175 p. [in Ukranian]

6. Poltorak, V. M., 2018. U chotyrykutnyku yevropeiskykh stolyts: Mykhailo Chaikovskyi ta osmanski kozaky v modernizatsii Pivdenno-Skhidnoi Yevropy. Odesa. 212 p. [in Ukranian]

7. Rybak, M., 1971. Mykhailo Chaikovskyi - Mehmet Sadyk Pasha. Almanakh ukrainskoho natsionalnoho soiuzu. Niu-York. p. 86-97. [in Ukranian]

8. Stoichev, Y. K., 1944. Kazak-alaia na Chaikovsky. Sofyia. [in Bolgarian]

9. Chaikovskyi, M., 1898. Zapysky. Russkaia staryna, 95(9), p.673. [in Russian]

Отримано: 29.11.2020 p. 